\author{
https://doi.org/10.52449/1857-4114.2020.35-1.03 \\ CZU: 616.711+373.037:373.2
}

\title{
THE IMPACT OF THE SPINAL DEFICIENCIES PROPHYLAXIS UPON THE 6-7 YEAR- OLD PRESCHOOL CHILDREN PHYSICAL DEVELOPMENT LEVEL
}

\author{
Buciu Daniela ${ }^{1}$ \\ ${ }^{1}$ Clinical Hospital CF no 2, Bucharest, Romania
}

\begin{abstract}
The problem of prophylaxis of various deficiencies of the skeletal bone of preschool children and first of all of the spine, as a basic pillar in their development, was and remains in the sights of specialists in the field of physical education and sports. It has been shown experimentally that the means of physical education can and must be a basic support in terms of spinal deficiencies prophylaxis, especially in children of preschool age, in this case the age of 6-7 years. It is at this age that the first symptoms occur related to the appearance of one or another spine deficiency. If no direct action is taken, with the application of specific means to eliminate or reduce the occurrence of these deficiencies, the situation may become much more serious and much more difficult to resolve. In this case, a series of means of physical education are proposed in the form of complex exercises and dynamic games, which have been used successfully in the training process of preschoolers aged 6-7. At the same time, the influence of the prophylaxis process of spinal deficiencies on the level of physical development of the contingent given by children was researched.
\end{abstract}

Keywords: deficiencies, preschoolers, physical development, spine coloumn.

In recent years, both in Romania [7, 15, 16] and in other European countries [3, 5, 6, $17,18]$ quite often has been and is treated the issue of training and physical development of children from preschool institutions. In this sense, the specialists come up with a series of organizational solutions, either in sports activities, which are mandatory in kindergartens, or in other forms of organizing physical education such as morning refreshments, active breaks, competitions with dynamic games etc.

At the same time, very little research is devoted to the study of malfunctions of the musculoskeletal system, including the spine in preschoolers. The need to study this problem stems from the fact that the results of several studies $[1,3,4,8,13$, ] have shown that there is an impressive number of primary school students, ie those who come from preschools, with different deficiencies of the human skeleton, and among these the most common are those of the spine. Among the most common deficiencies of the spine are scoliosis, kyphosis and lordosis. Specialists propose in this regard, the widespread use of the means of physical education, ie physical exercises, for the prophylaxis and treatment as far as possible of these defects. The vast majority of specialists $[3,6,7,10,16,17,18]$ consider that these deficiencies are easier to prevent than to be treated later, which can be quite difficult, and it can only be done in a purely medical or surgical way.

Starting from the confirmations of several authors $[1,2,9,12,14,15]$ made above, we can mention that at present there is no wellargued scientific methodology that would propose a way to prevent scoliotic diseases of spine in preschool children, more specifically those aged 6-7 years.

In this direction, a pedagogical experiment was organized with a duration of one year of study, which aimed at the prophylaxis of 
spinal deficiencies in children aged 6-7 by applying the means of physical education in the form of complexes of special exercises and dynamic games applied in in kindergartens, as well as at home under parental supervision.

Thus, a sample of preschoolers was selected in total number of 522 children from six preschool institutions in Bucharest, of which 255 boys and 257 girls, aged between 6 and 7 years. All these children were also examined at several parameters related to the assessment of the motor training level, physical and functional development, as well as highlighting the deficiencies of their spine.

The above mentioned directed us to look for effective ways to improve the situation in this regard, referring primarily to the prophylaxis of spinal deficiencies of preschoolers by applying the means of physical education in their training. At this stage, a pedagogical model of application of the means of physical education within the physical education with the preschoolers of 67 years was made (Figure 1).

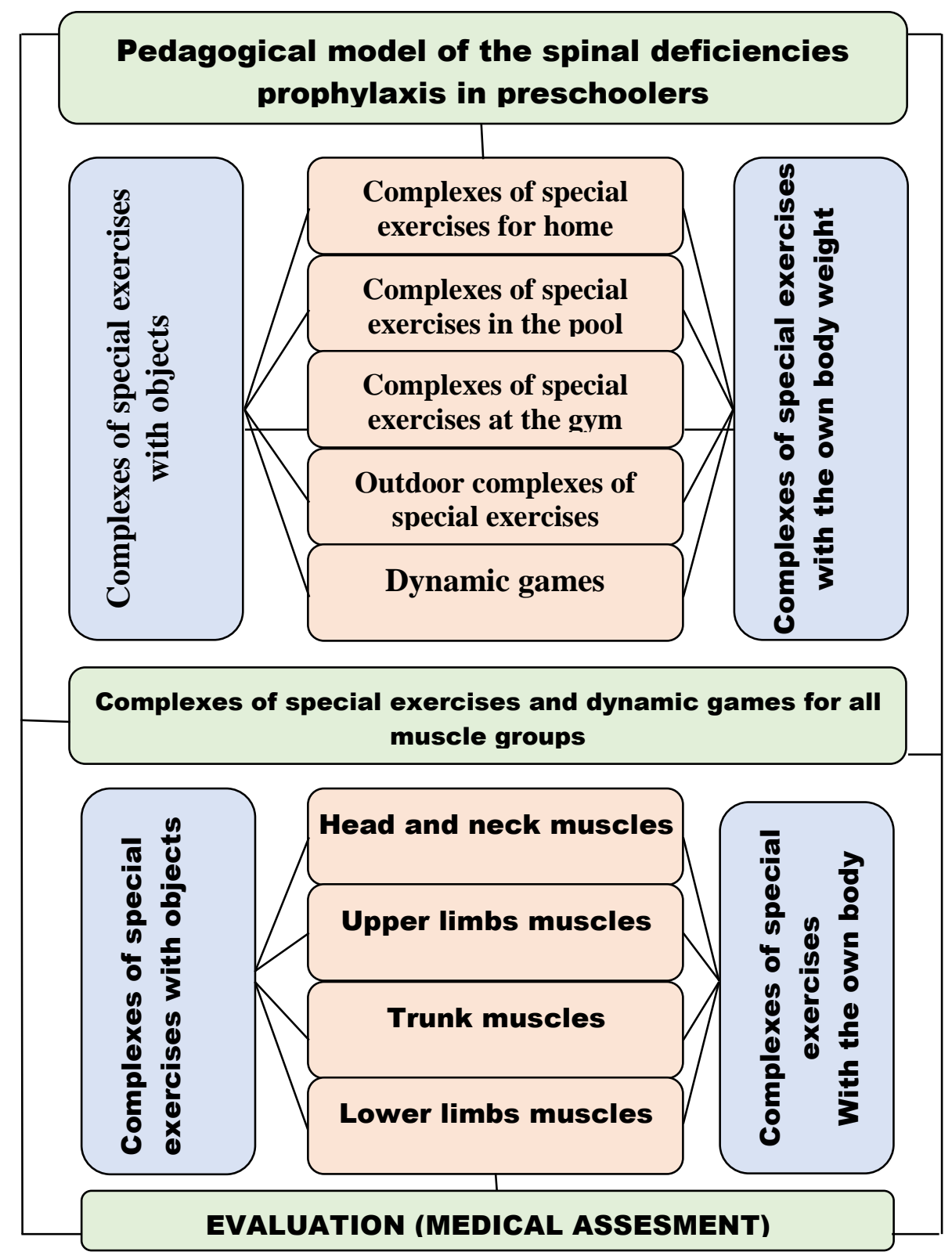

Fig. 1. Pedagogical model of the spinal deficiencies prophylaxis in preschoolers 
In fact, the given model focuses on three general compartments, these being the place of sports activities, the destination of the means proposed for application in the training process and the assessment of the spine of children following the application of the means described in the model. Both block one and block two of the given model focused on two large groups of means, these being the exercises with objects and the exercises without objects.

The children from the given institutions carried out physical education activities every day, the duration of each being 30 minutes. The exercise complexes were made up in time, either in written or graphic form and were modified, depending on the objectives of the physical education activities, once a week or at least once in two weeks.

All physical education activities, within preschool institutions, were carried out under the strict control of the specialized teacher. If we analyze the pedagogical model, it is clear that the basic activity of physical education is carried out in specialized lessons, as a basic and compulsory form in preschool institutions. The way of performing the exercise complexes was quite simple where the teacher carried out an exercise complex, and at the end of the sports activity a dynamic game was organized with concrete tasks, based on its objectives.

However, the children permanently received some individual tasks so that they could be performed at home under parental control. The content of each task was strictly specified by the teacher with the indication of the number of repetitions for each exercise, ie the dosage of physical effort.

At the end of the pedagogical experiment, where the emphasis was on the prophylaxis of spinal deficiencies, we were especially interested in how the indices of physical development in children in the experiment evolved.

In the experiment, five parameters were analyzed, according to us, the most important in children's development, these being the height, weight, strength of the right hand and the strength of the left hand, the thoracic perimeter. These data were collected in Bucharest (Romania) between September 2017 and May 2018, and the results were statistically processed and are presented in Table 1.

Table 1. The results of the aged 6-7 preschoolers physical development in the pedagogical experiment

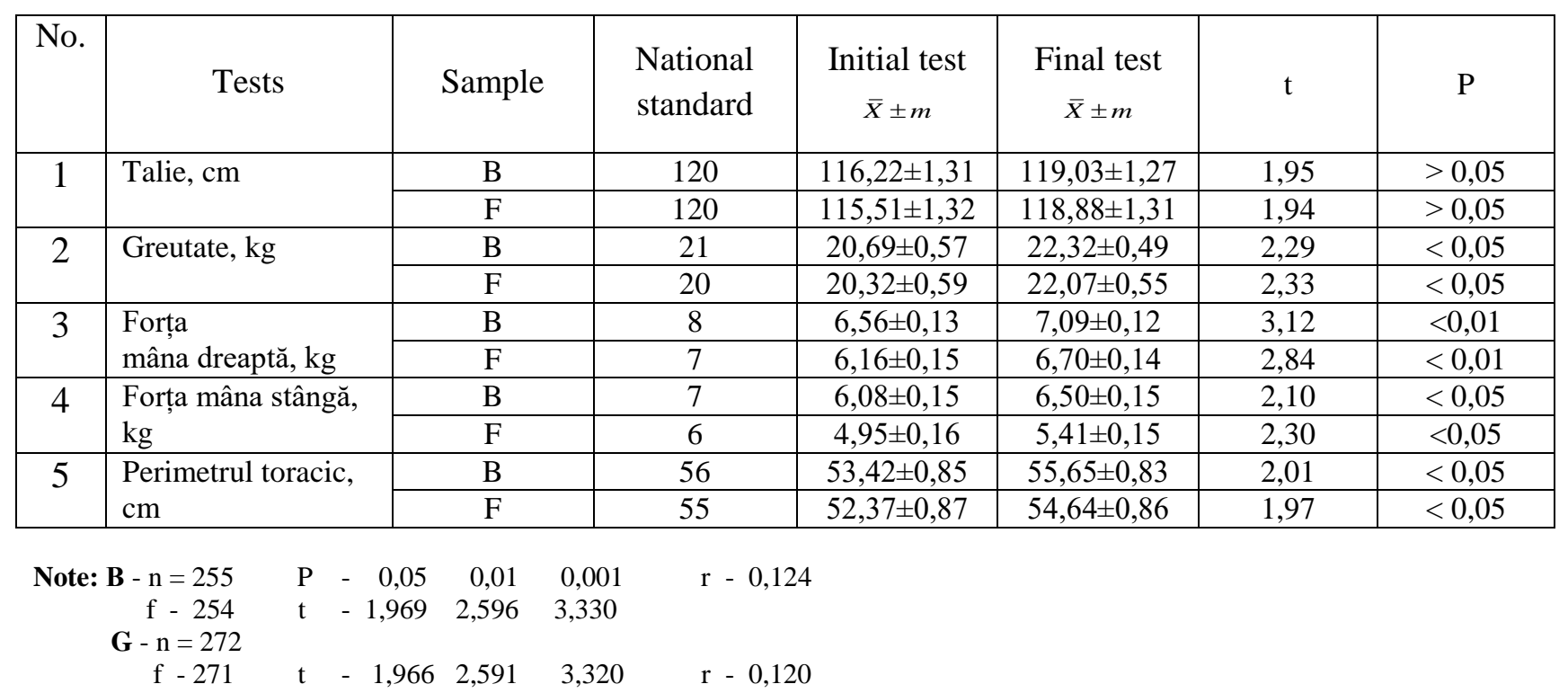


Analyzing the table above we notice that in the vast majority of indicators tested there were quite obvious changes, this being confirmed by statistical calculations, where only the first indicator (height) did not have a statistically significant increase $(\mathrm{P}>0,05)$, although the children registered an increase of over 3 centimeters and came very close to the national standards for this indicator. The results are very well visualized in Figure 1.

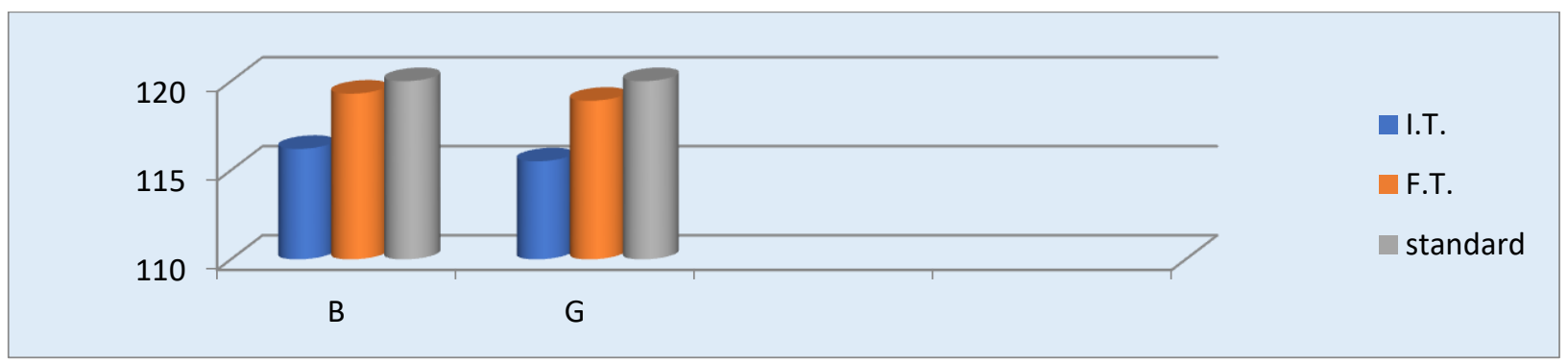

Fig. 1. The height tests results of the preschoolers in the pedagogical experiment

According to several specialists, height cannot be radically influenced, even by applying the means of physical education, this being a stable indicator, one that largely depends on the genetic predisposition of each individual.

Another indicator representing the level of physical development of preschool children was body weight (Figure 2).

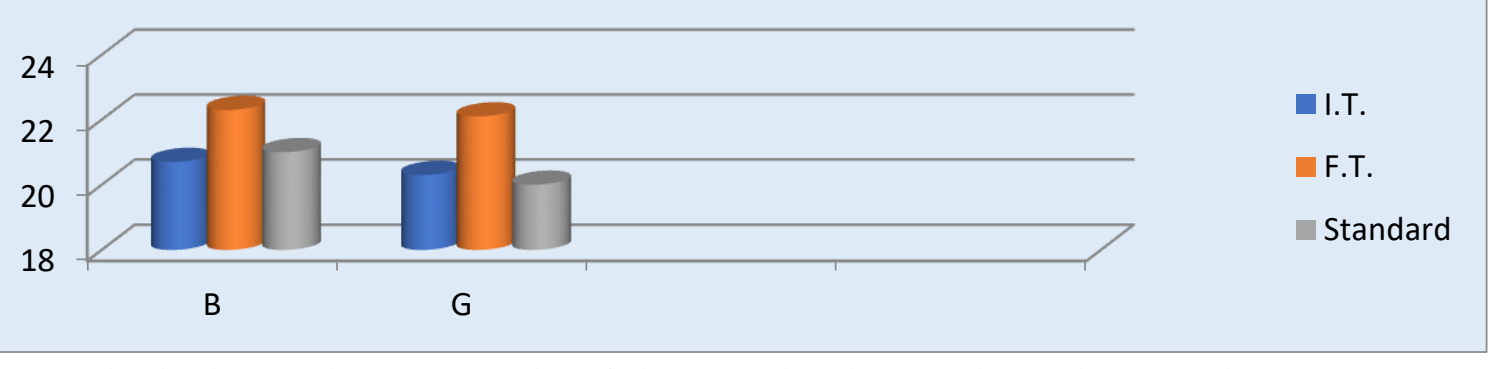

Fig. 2. The body weight tests results of the preschoolers in the pedagogical experiment

Unlike the first indicator, body weight can and should be constantly checked and kept under the strict control of parents and teachers in physical education and sports. This indicator is largely related, firstly, to the children's motor regime and secondly to their diet.

If we analyze the evolution of this indicator, we notice that it has a contoured rise, ie the children's body mass is increasing and both at the beginning and at the end of the experiment, children exceeded the national weight standard for that age, which in boys is equivalent to 21 kilograms, and in girls to 20 kilograms. At the initial test they weighed
20.69 kilograms, and at the end of the experiment they reached a body weight of 22.32 kilograms. The girls initially weighed 20.32 kilograms, and at the end of the experiment they reached 22.07 kilograms. In both cases the statistical calculations showed that the differences between the initial and the final test are significant $(\mathrm{P}<0.05)$.

Therefore, children aged 6-7 years have a body weight that exceeds the national standard, and this can lead not only to worsening health, but also to the appearance of motor deficiencies and primarily the spine, which at this age is quite sensitive and easily affected. 
Next we will analyze the muscular strength of children's hands (Figure 3 and 4). If we follow the evolution of the muscular strength of the right hand, we notice that at the beginning of the pedagogical experiment the children in the environment recorded a result equivalent to 6.56 kilograms, at the end of which the muscular strength of the right hand reached 7.09 kilograms (Figure 3).
If we analyze the statistical calculations, it is clear that the difference between the initial and the final test is statistically significant $(\mathrm{P}$ $<0.05)$, although the national standard for this age is 8 kilograms, a result that children they do not touch him at the beginning or at the end of the pedagogical experiment.

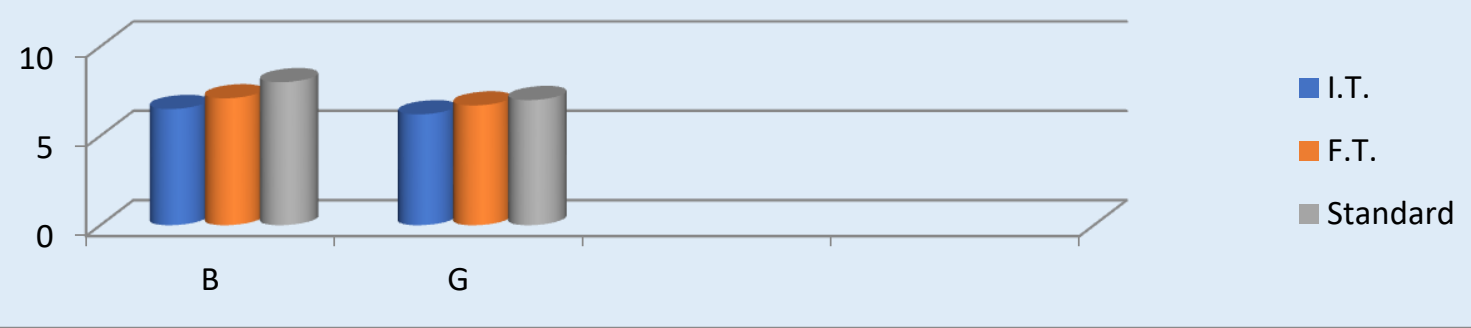

Fig. 3. The strength of children's right hands tests results of the preschoolers in the pedagogical experiment

The evolution of the strength of the left hand in boys and girls does not differ much (Figure 4), where at the beginning of the experiment the boys registered an average equal to 6.08 kilograms, and at the end 6.50 kilograms. The girls had an initial result equal to 4.95 kilograms, and at the end of the experiment it increased to 5.41 kilograms. In both cases the differences between the initial and the final test were statistically significant $(\mathrm{P}<0.05)$.

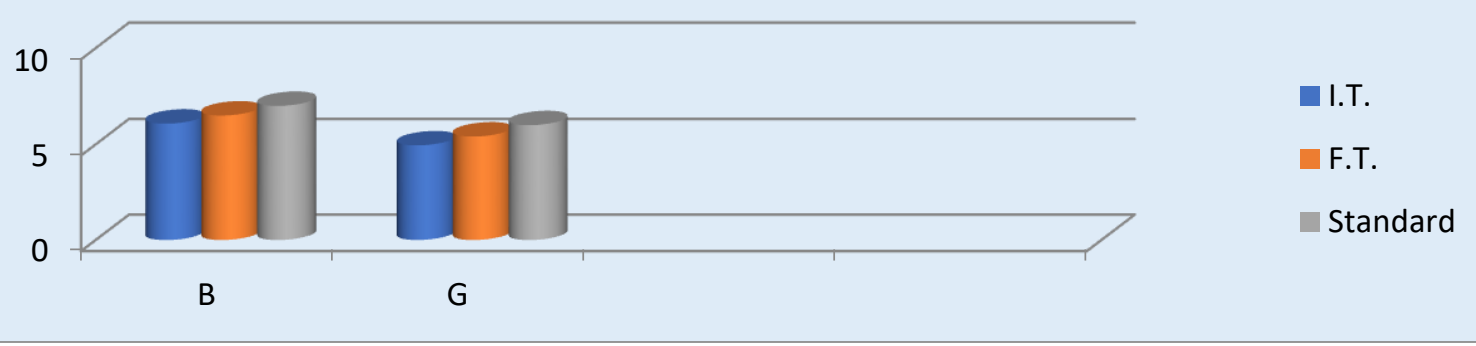

Fig. 4. The strength of children's left hands tests results of the preschoolers in the pedagogical experiment

Thus, we notice that even in this case, when it comes to the muscular strength of the hands of children aged 6-7, although they can be influenced by applying different methodologies, this does not happen, which tells us about the inadequacy of the use of physical education, such as physical exercise in any form, in the process of their training.

The last indicator tested in the physical development of the children participating in the pedagogical experiment was that of the thoracic perimeter (Figure 5). 


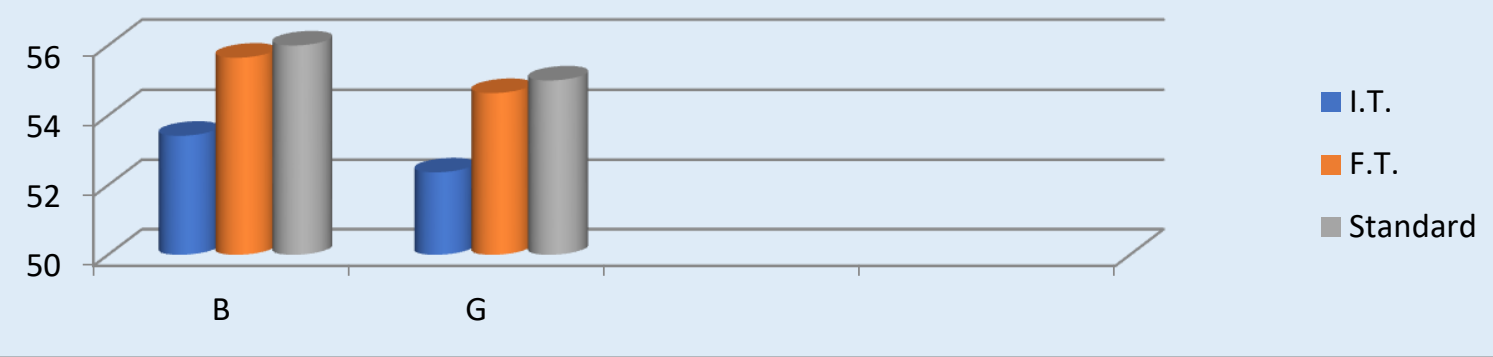

Fig. 5. The thoracic perimeter tests results of the preschoolers in the pedagogical experiment

The thoracic perimeter represents the level of development of the children's chest, which can be influenced by the widespread use of the means of physical education in various forms, including at home. As shown in Figure 2.12. neither boys nor girls exceed the national standard for this indicator, but at the end of the experiment the results are quite close to this standard, where for boys it is equivalent to 56 centimeters, and for girls - 55 centimeters. It is worth mentioning that at the beginning of the pedagogical experiment the boys recorded a result equal to 53.42 centimeters, and at the end of it reached values of 55.65 centimeters, a result that is quite close to the national standard. The girls at the initial test had a result equal to 52.37 centimeters, and at the end of the experiment 54, 64 centimeters, being very close to the national standard (55 centimeters).

Analyzing the differences between the initial and final results on this indicator, we note that they are statistically significant $(\mathrm{P}$ $<0.05$ ), ie the application of physical education in the training of preschoolers had a positive effect on this indicator and in general on all indicators tested in the chapter on physical development.

In general, according to the data recorded in the physical development department, based on the results of the training experiment, it is very clear that they are not very varied and do not differ significantly from the national standards for this age, both boys and girls. Only an indicator related to body weight, the results of the contingent tested, prevail over the standards for that age. The other results are below the limit of the standards, but do not represent significant differences in this respect, ie it can be confirmed that children of a given age, boys and girls, have a normal level of development and the recorded data can not be significantly improved through the application of means from physical education. For example, body weight is the result of maintaining or not maintaining a balanced diet and of course the limited amount of time given to exercise.

Therefore, using the means of physical education for the prophylaxis of spinal deficiencies of children aged 6-7 years, the indicators of physical development do not suffer, but conversely, can be improved depending on their content.

Thus, physical education teachers in preschool education will take into account the age peculiarities of preschoolers, in this case, those aged 6-7, where they will not abuse the strength exercises for boys and girls, instead they will have the possibility of using other means for the normal physical development of children and for preventing the increase of their body weight.

\section{References:}

1. Buciu D. (2017). Spine disorders prophylaxis in preschool physical education classes. ISSC Interdisciplinary research in the training of future professionals in the field: Science of sport and physical eduction, 17-18 mai. Bacau, p. 79. 
2. Calais-Germain B. (2018). Anatomie pentru mișcare, vol. I. În: Introducere în analiza tehnicilor corporale (ediţia a II-a). Iasi: Editura Polirom. 312 p.

3. Carp I., Decusar N. (2010). Dinamica indicilor dezvoltării fizice la preşcolari în cadrul activităţilor de educaţie fizică. În: Materialele Conferinţei Ştiinţifice Internaţionale Studenţeşti „Probleme actuale ale teoriei şi practicii culturii fizice”, ediţia XIV-a. Chişinău: USEFS, p. 58-64.

4. Caun E., Dorgan V. (2006). Educaţia fizică a elevilor cu deficienţe de coloană. În: Teoria şi arta educaţiei fizice în şcoală, nr 2. Chişinău, p. 52-54.

5. Ciorbă C. (2016). Teoria și metodica educației fizice. Chișinău: Valinex SRL. 139 p.

6. Ciorbă C., Buciu D. (2019). Particularitățile profilaxiei deficiențelor coloanei vertebrale la preșcolarii de 6-7 ani. Revista „Studia Universitatis Moldaviae”, nr.5 (125), seria: Științe ale Educației, p.94-101.

7. Constantinescu M. (2015). Abordarea deficiențelor fizice funcționale a coloanei vertebrale din punct de vedere profilactic folosind metoda observației. În: Conferința Ştiinţifică Internațională „Probleme actuale privind perfecționarea sistemului de învățământ în domeniul culturii fizice”. Chișinău, p. 349.

8. Dinu M. Antonescu (2018). Patologia aparatului locomotor. București: Editura Medicală. $324 \mathrm{p}$.

9. Drăgan I. (2002). Medicină Sportivă. București: Ed. Medicală, p. 35-124.

10. Fozza C.A. (2002). Indrumar pentru corectarea deficiențelor fizice. București: Ed. Fundației România de Mâine, p.7, 10-13.

11. Jianu M. (2011). Diagnostic precoce şi tratament în scolioza idiopatică. Bucureşti: Pro Editura și Tipografie. $119 \mathrm{p}$.

12. Mîrza D. (2005). Kinetoprofilaxia primară. Iaşi: Editura Tehnopress. 138 p.

13. Obrascu C., Antonescu D., Ovezea A. (2017). Corectarea coloanei vertebrale. Bucureşti: Editura Medicală. 220 p.

14. Pehoiu C. (2004). Continuitatea activității de educație fizică în învățământul preșcolar, primar și gimnazial. Târgoviște: Cetatea de scaun. 247 p.

15. Raportul național de sănătate a copiilor și tinerilor din România, Institutul Național de Sănătate Publica, București, 2017. http://insp.gov.ro/sites/cnepss/wp-content/uploads/2018/02/rsc2017.pdf

16. Tuchilă I. (2012). Recuperarea scoliozei la elevii din ciclul primar în procesul educaţiei fizice, teză de dr. în științe pedagogice. Chișinău. 134 p.

17. Дубровский В.И. (2005). Спортивная физиология: Учебник для средних и высших учебных заведений по физической культуре. Москва: Владос. 462 с.

18. Попов С.Н. (2008). Лечебная физическая культура. Ростов на Дону: Феникс. 261 с. 